\title{
The sense of coherence and sense of satisfaction with life in patients hospitalized in Polish and Irish surgical departments
}

\author{
Krzysztof Kamil Kotulski, ${ }^{1, A, B, D}$, Joanna Bartczak-Kotulska ${ }^{2, B, C}$, \\ Julia Rudno-Rudzińska',E, Wojciech Kielann, ${ }^{1, E, F}$ Ewelina Frejlich ${ }^{1, C}$, Wojciech Hap ${ }^{1, B}$ \\ ${ }^{1}$ Clinic of General and Oncological Surgery, Jan Mikulicz-Radecki University Teaching Hospital, Wrocław, Poland \\ ${ }^{2}$ Joanna Bartczak-Kotulska Center for Psychoeducation and Therapy, Ostrowina, Poland \\ A - research concept and design; $B$ - collection and/or assembly of data; $C$ - data analysis and interpretation; \\ $\mathrm{D}$ - writing the article; $\mathrm{E}$ - critical revision of the article; $\mathrm{F}$ - final approval of the article
}

Address for correspondence

Krzysztof Kotulski

E-mail:k.kotulski@mp.pl

Funding sources

None declared

Conflict of interest

None declared

Received on June 26, 2017

Reviewed on November 10, 2017

Accepted on August 9, 2018

Published online on July 20, 2021

Cite as

Kotulski KK, Bartczak-Kotulska J, Rudno-Rudzińska J, Kielan W, Frejlich E, Hap W. The sense of coherence and sense of satisfaction with life in patients hospitalized in Polish and Irish surgical departments. Adv Clin Exp Med. 2021;30(8):813-822. doi:10.17219/acem/94156

DOI

10.17219/acem/94156

Copyright

Copyright by Author(s)

This is an article distributed under the terms of the

Creative Commons Attribution Non-Commercial License

(http://creativecommons.org/licenses/by-nc-nd/4.0/)

\section{Abstract}

Background. The concept of the sense of coherence (SOC) - the global orientation of life, created by Aaron Antonovsky - is increasingly popular. This study within the field of health psychology examines the situation of patients awaiting surgery in Poland and Ireland.

Objectives. To investigate the relationship between the strength of the SOC and its components (comprehensibility, manageability and meaningfulness) and the level of satisfaction with life (SWL) of patients hospitalized in surgical departments in hospitals in Poland and Ireland.

Materials and methods. The research was conducted in a group of 60 surgical patients, including 30 hospitalized in Poland and 30 in Ireland. The tools utilized were the Sense of Coherence Questionnaire for Adults SOC-29 and the Satisfaction with Life Scale (SWLS). Polish versions of both questionnaires were also used

Results. We obtained the following results:

- for comprehensibility: in patients undergoing surgery in hospitals in Poland, the mean $(M)=46.3$, standard deviation $(S D)=9.8$, minimum value $($ Min $)=28$, and maximum value $(\operatorname{Max})=63$; in Irish patients, $M=50.8, S D=9.2, \operatorname{Min}=33$, and $\operatorname{Max}=71$;

- for manageability: in patients undergoing surgery in hospitals in Poland, the $M=49.7, S D=5.07$, Min $=37$, and $M a x=58$; in Irish patients, $M=49.3$ SD = 6.39, Min = 38, and $M a x=63$;

- for meaningfulness: in patients undergoing surgery in hospitals in Poland, $M=45.5, S D=4.24$, Min $=37$, and $M a x=54$; in Irish patients, $M=44.9$ SD $=5.74$, Min = 34, and $M a x=56$.

Conclusions. The results of the study confirmed the assumption that a general SOC correlates with SWL. However, they did not confirm the hypothesis that differences in the strength of patients' SOC, its components and their level of SWL depend on the country of hospitalization.

Key words: life satisfaction, sense of coherence, salutogenesis, surgical patient 


\section{Background}

\section{The sense of coherence as the central concept of salutogenesis}

The sense of coherence (SOC) has been a concept in psychology for over 30 years. The originator of the concept is Aaron Antonovsky, a medical sociologist. ${ }^{3}$ The inspiration for this concept was his analysis of the living situation (including health) of the survivors of concentration camps. Antonovsky sought an answer to the question of why some people, despite extremely difficult experiences, survived and lived long lives, maintaining optimism and serenity, while others lost their desire to live, became bitter and, after regaining freedom, became ill and died. Antonovsky sought to explain what determines that some people maintain their health, living a long and active life, while others are more likely to fall ill, recover with difficulty and live shorter lives as a result. The answer Antonovsky found was that the observed differences are caused by the way we comprehend ourselves and the world, by a sense of the meaningfulness of our lives and our actions, and a sense of possessing qualities that enable us to manage life successfully. These 3 elements are the ingredients of the notion of the SOC - the most important concept in Antonovsky's concept of health, which is called salutogenesis.

In this approach, health is considered the current position on a continuum of health-illness, where the left pole is characterized as a state of full mental, physical and social health, while the right pole is the state of profound, life-threatening illness. ${ }^{4}$ There are 2 types of approaches in the concepts of health: consideration and examination of health determinants (the salutogenic approach) and consideration and examination of the factors responsible for the appearance of disease (pathogenetic approach). Based on the research questions listed in the text, we formulated the research hypotheses presented in Table 1 . Table 2 presents the essential features of the salutogenic paradigm in comparison with the pathogenetic paradigm.

The notion of health in the salutogenic paradigm is related to the ability to cope with external and internal demands and burdens while maintaining a dynamic balance. ${ }^{5}$ Antonovsky outlines 4 key elements that affect an individual's health. These are: generalized resistance resources, stressors, SOC, and behavior and lifestyle. ${ }^{4}$

Antonovsky uses these concepts to explain why people maintain health despite experiencing stress and difficult conditions, or why - in the event of health problems - they quickly regain it. The answer is in the existence

Table 1. Hypotheses and detailed hypotheses

\begin{tabular}{|c|c|c|}
\hline SN & Hypotheses & Detailed hypotheses \\
\hline \multirow{3}{*}{1} & \multirow{3}{*}{$\begin{array}{l}\mathrm{H} 0 \text { : There is no correlation between } \\
\text { the strength of the sense } \\
\text { of coherence (SOC) and the level } \\
\text { of satisfaction with life (SWL). } \\
\mathrm{H1} \text { : There is a correlation between } \\
\text { the strength of the sense } \\
\text { of coherence (SOC) and the level } \\
\text { of satisfaction with life (SWL). }\end{array}$} & $\begin{array}{l}\text { Hypothesis 1A: } \\
\text { HO: There is no correlation between the comprehensibility component of the SOC and the level } \\
\text { of SWL. } \\
\text { H1: There is a correlation between the comprehensibility component of the SOC and the level of SWL. }\end{array}$ \\
\hline & & $\begin{array}{l}\text { Hypothesis 1B: } \\
\text { HO: There is no correlation between the manageability component of the SOC and the level of SWL. } \\
\mathrm{H1} \text { : There is a correlation between the manageability component of the SOC and the level of SWL. }\end{array}$ \\
\hline & & $\begin{array}{l}\text { Hypothesis 1C: } \\
\text { HO: There is no correlation between the meaningfulness component of the SOC and the level of SWL. } \\
\mathrm{H} 1 \text { : There is a correlation between the meaningfulness component of the SOC and the level of SWL. }\end{array}$ \\
\hline \multirow{3}{*}{2} & \multirow{3}{*}{$\begin{array}{l}\text { HO: There is no difference between } \\
\text { the strength of the SOC in Polish and } \\
\text { Irish patients. } \\
\mathrm{H1} \text { : There is a difference between } \\
\text { the strength of the SOC in Polish and } \\
\text { Irish patients. }\end{array}$} & $\begin{array}{l}\text { Hypothesis 2A: } \\
\text { HO: There is no difference between the levels of the comprehensibility component of the SOC in Polish } \\
\text { and Irish patients. } \\
\mathrm{H1} \text { : There is a difference between the levels of the comprehensibility component of the SOC in Polish } \\
\text { and Irish patients. }\end{array}$ \\
\hline & & $\begin{array}{l}\text { Hypothesis 2B: } \\
\text { H0: There is no difference between the levels of the manageability component of the SOC in Polish } \\
\text { and Irish patients. } \\
\mathrm{H1} \text { : There is a difference between the levels of the manageability component of the SOC in Polish and } \\
\text { Irish patients. }\end{array}$ \\
\hline & & $\begin{array}{l}\text { Hypothesis 2C: } \\
\mathrm{HO} \text { : There is no difference between the levels of the meaningfulness component of the SOC in Polish } \\
\text { and Irish patients. } \\
\mathrm{H1} \text { : There is a difference between the levels of the meaningfulness component of the SOC in Polish } \\
\text { and Irish patients. }\end{array}$ \\
\hline 3 & $\begin{array}{l}\text { H0: There is no difference between } \\
\text { the levels of SWL in Polish and Irish } \\
\text { patients. } \\
\text { H1: There is a difference between } \\
\text { the levels of SWL in Polish and Irish } \\
\text { patients. }\end{array}$ & - \\
\hline
\end{tabular}


Table 2. A comparison between the salutogenic paradigm and the pathogenic paradigm

\begin{tabular}{|l|l|}
\multicolumn{1}{|c|}{ Pathogenic paradigm } & \multicolumn{1}{c}{ Salutogenic paradigm } \\
\hline Thinking about people: either healthy or sick & Thinking about health and illness within the continuum from health to disease \\
Concentration on one specific pathological unit & Communicating with all who work on exploring the mystery of health \\
\hline $\begin{array}{l}\text { Studying the causes of disease } \\
\text { All the stressors are bad }\end{array}$ & Focus on resources to help deal with stress \\
\hline $\begin{array}{l}\text { It is important to declare war on the disease and } \\
\text { overcome it }\end{array}$ & $\begin{array}{l}\text { How to learn to live in health with stressors and take advantage of them } \\
\text { contribution to the social system }\end{array}$ \\
\hline $\begin{array}{l}\text { Priority for individual cases and high-risk groups } \\
\text { People should be taken care of at every point of the health-disease continuum }\end{array}$ \\
\hline
\end{tabular}

of so-called generalized resistance resources, understood as "[...] characteristics of the natural, material and sociocultural environment, characteristics of the organism and psychological characteristics of the individual that are beneficial for the management of stress". ${ }^{1}$ The functional value of generalized resistance resources is that they allow the individual to avoid stressors and influence the ability to cope with internal and external demands by preventing the transformation of tension into stress while promoting health care. ${ }^{6}$ Initially, the author defines stressors as the conditions for which there are no ready responses. Due to the lack of ready responses, tension appears. ${ }^{5}$ He then adds, however, that stressors are linked to overburden, a low level of involvement or a lack of involvement in decision-making. Antonovsky proposes that stressors should be perceived in relation to the continuum of resistance resources - as resource deficits. The more resistance resources a person possesses, i.e., the closer they are to the resources on the continuum, the more their experience will foster the development of a SOC. ${ }^{1}$ Therefore, Antonovsky regards as a stressor any factor that causes tension by increasing demands or creating new ones, necessitating a new way of responding. He emphasizes that a stressor can also act as a mobilizer, mobilizing and releasing energy, and strengthening resistance as a result. In a situation when the resources and the individual's own energy are inadequate and ineffective in coping with demands (stressors), then tension transforms into stress, which leads to a health breakdown and the occurrence of disorders. ${ }^{6}$

According to Antonovsky, the key element influencing the method and quality of functioning of generalized resistance resources is the SOC. The SOC has a motivational function in the active handling of demands, and a regulatory function, controlling the selection of resources relevant to current requirements. ${ }^{6}$ The greater the intensity of the SOC, the more efficient and adequate is the use of resources and coping strategies. Therefore, coping with stress and tension depends on the adequate use of resources, which is linked to the strength of one's SOC.

In Antonovsky's concept, SOC is defined as "a global orientation that expresses the extent to which one has a pervasive, enduring yet dynamic feeling of confidence that one's internal and external environments are structured and predictable, and the feeling of the probability of a positive turn of events, expected on the basis of rational premises". ${ }^{1}$ He goes on to broaden the definition by adding that the SOC is related to the fact that "1) the stimuli deriving from one's internal and external environments in the course of living are structured, predictable and explicable; 2) the resources to meet the demands posed by these stimuli are available to one; and 3) these demands are challenges, worthy of investment and engagement". The author does not equate the SOC with a personality trait. He uses the phrase "dispositional orientation", which is correlated with comprehensibility, manageability and meaningfulness. ${ }^{1}$

Describing in detail the dynamics of coherence in the human development cycle, Antonovsky emphasizes the importance of the process of socialization. According to the author, achieving a certain level of the SOC is a result of individual coherent life experiences created in interaction with the environment. However, the SOC can be defined as a relatively constant trait only at the beginning of adulthood, when a socio-cultural context is established, related to (among other things) the roles one takes on, the work one undertakes and lasting relationships. ${ }^{1}$

Antonovsky initiated a new processual understanding of the notion of health. He defined health as a process of balancing requirements (stressors) and resources. Health maintenance is therefore the use of available resources to meet external and internal requirements without permanently disrupting the dynamic balance between burdens and possibilities. ${ }^{1}$ The most important factor - "the key to health", as the author puts it - is the SOC, which is a meta-resource of the individual. ${ }^{6}$

\section{The concept of satisfaction with life in literature and psychological research}

The concept of satisfaction with life (SWL) has been discussed in numerous works and is often associated with such concepts as quality of life (QOL), prosperity and happiness. Since the mid- $20^{\text {th }}$ century, it has been of interest to many scientific disciplines, including medicine, sociology, economics, and psychology. The literature on the subject cites many definitions of levels of SWL and QOL viewed from different perspectives, e.g., Cummins, Dieber, Czapiński, Sęk and Heszen, Schipper, Levin, Argyle, de WaldenGałuszko, and many other researchers. However, no single 
coherent definition has yet been established that would address the issue from an interdisciplinary perspective. ${ }^{3}$

The state of health can be assessed objectively, from the point of view of an observer (e.g., a doctor) or subjectively, from the perspective of the individual. ${ }^{6}$ One element of a subjective evaluation is the level of SWL, also called the QOL, happiness or prosperity. The concept of the "quality of life" is rooted in positive psychology, which focuses primarily on the promotion and multiplication of happiness. ${ }^{7}$ As emphasized by R.A. Kane, for some the QOL is a very broad concept in which almost everything is significant, while for others it includes only some elements of life. ${ }^{8}$

According to the findings of the International Society for Quality of Life Research (ISOQOL), the concept of the "quality of life" has 2 main underlying principles:

1. The concept of QOL as a practical (not necessarily strictly defined) concept in social policy and in evaluating services offered by it, as well as useful in evaluating various initiatives and programs undertaken at the local, national and international levels.

2. The overriding importance of individual perception and the subjective perspective of the individual regarding their QOL. ${ }^{9}$

The multidimensional nature of the concept of the QOL is also emphasized, highlighting the link between QOL and individual and environmental factors, such as intimacy, family life, friendship, work, neighborhood, place and living conditions, education, health, standard of living, and nationality. ${ }^{10}$

An interesting definition was put forward by Raphael et al., who defined QOL as "the degree to which a person enjoys the important possibilities of his/her life". ${ }^{11}$ The authors list 3 main areas from the perspective of which they study the concept of QOL: being - individual attributes of the individual; belonging - matching the person and the environment; and becoming - realizing oneself (see Table 3 for details).

According to the assumptions formulated by Schalock, QOL consists of 8 components: emotional well-being,

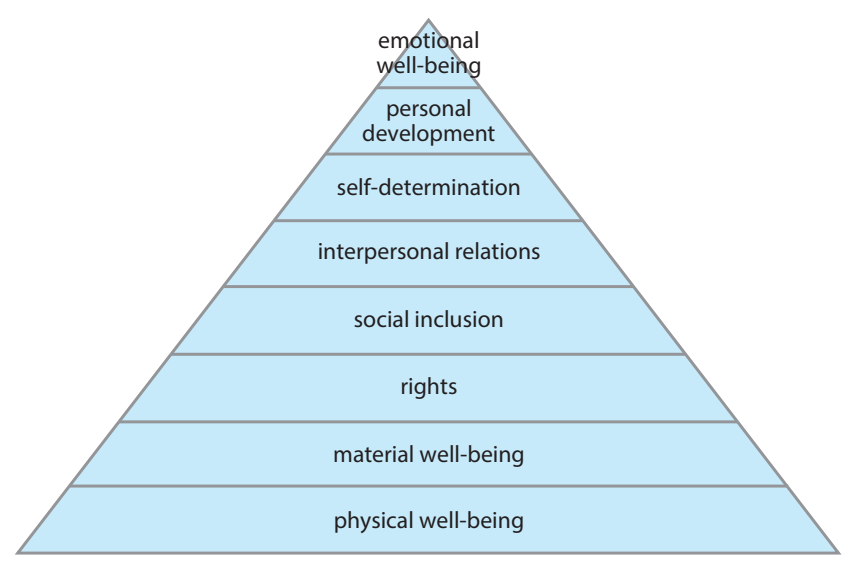

Fig. 1. Quality of life in a hierarchical perspective

interpersonal relations, material well-being, personal development, physical well-being, self-determination, social inclusion, and individual rights. ${ }^{12}$ The author presents QOL in a multidimensional and dynamic perspective, emphasizing the hierarchical dependence of these 8 factors, as shown in Fig. 1. At the same time, the author draws attention to the interactions of the individual with the environment, including the educational and medical contexts. $^{12}$

Cummins, on the other hand, points to both the objective and subjective dimension of QOL, each of which is characterized by 7 identical factors. These are: standard of living, health, life achievements, relationships with other individuals, personal security, relationships with the community, and securing the future. The subjective dimension is related to the sense of SWL. The researcher proposed a homeostatic model of the subjective QOL, presented in Fig. 2, according to which 3 groups of factors determine the degree of SWL:

1. Determinants of the $1^{\text {st }}$ order: personality, i.e., extraversion and neuroticism, strongly correlated to one's sense of QOL.

2. Determinants of the $2^{\text {nd }}$ order: so called internal buffers, i.e., control, self-esteem and optimism, which have

Table 3. Areas of the quality of life (QOL)

\begin{tabular}{|c|c|c|}
\hline Main areas & Sub-areas & Detailed description \\
\hline \multirow{3}{*}{ Being } & physical & health, personal hygiene, nutrition, movement, care, dress, exterior appearance \\
\hline & mental & mental health and adaptation, perception, emotions, self-evaluation and self-control \\
\hline & spiritual & personal values, lifestyle, beliefs \\
\hline \multirow{3}{*}{ Belonging } & physical & relationship with the physical environment, e.g., home, workplace, neighborhood, school, community \\
\hline & social & $\begin{array}{l}\text { relationship with the environment regarding the acceptance and kindness of others, e.g., family, friends, } \\
\text { co-workers, neighbors }\end{array}$ \\
\hline & local & $\begin{array}{l}\text { equal and adequate access to social resources such as income, healthcare, social welfare, employment, } \\
\text { education, recreation, celebrations }\end{array}$ \\
\hline \multirow{3}{*}{ Becoming } & productivity & $\begin{array}{l}\text { planning and regular activities taking into account the needs of the individual, concerning, e.g., home, work, } \\
\text { education }\end{array}$ \\
\hline & free time & rest, relax, stress reduction \\
\hline & personal development & classes developing knowledge and skills \\
\hline
\end{tabular}




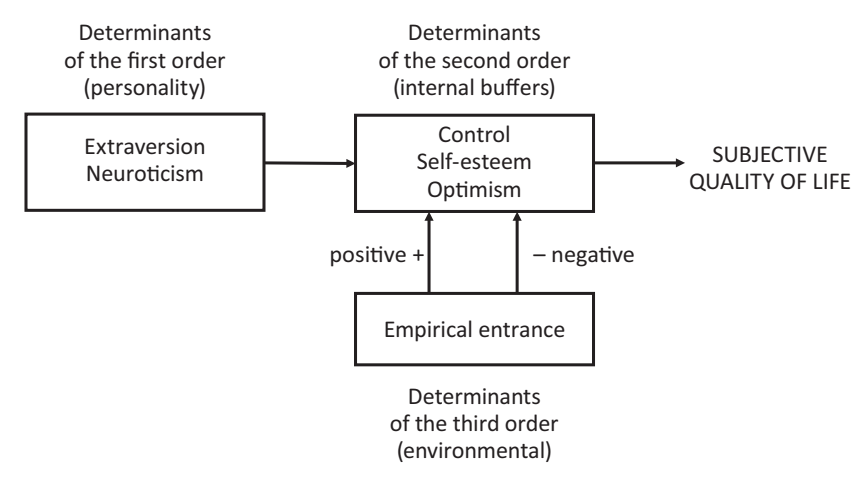

Fig. 2. Homeostatic model of the subjective quality of life (QOL)

the function of alleviation in the event of the deterioration of external conditions.

3. Determinants of the $3^{\text {rd }}$ order: the personal experience of the individual.

According to Shin and Johnson, SWL is an "overall assessment of QOL in relation to selected criteria". ${ }^{2}$ If the assessment is positive, it is assumed that the person feels satisfied with his/her life. Diener, on the other hand, lists SWL, in addition to the presence of positive feelings and the absence of negative feelings, as elements of so-called well-being. ${ }^{2}$ According to Sęk and Heszen, QOL can be associated with the predominance of positive emotions, the level of satisfaction of needs, an abundance of goals, activity, commitment, and a positive attitude towards life. These concepts can be considered from an objective and a subjective perspective. The objective perspective refers to a person's living and working conditions, i.e., to their physical, material and socio-cultural conditions. The subjective determinants, on the other hand, are the evaluation of life as a whole and its individual elements. It should be noted that there are no simple relations between these 2 perspectives. Sęk points to persons who, despite difficult objective conditions, value life positively, due to a sense of influence over their own life and the skillful use of resources. ${ }^{4}$

Discussing the relationship between the SOC and the level of SWL, we will refer to the subjective perception of QOL. The aim of the study was an attempt to answer the question of whether there is a link between the strength of the SOC in patients undergoing surgery in Poland and Ireland and the level of their SWL.

\section{Objectives}

The main goal of the study was to examine the relationship between the SOC and its components (comprehensibility, manageability and meaningfulness), and the level of SWL in patients hospitalized in surgical departments in hospitals in Poland and Ireland. The main assumptions were:

1. the hypothesis that there is a relationship between the variables tested; and
2. the hypothesis that there is a difference in the SOC and SWL between the 2 study groups, with higher values assumed for the Irish patients, as a result of higher living standards, including medical and social care.

Also, so-called contextual variables, such as age, sex, place of residence, level of education, marital status, and the reason for hospitalization, the length of the hospital stay, the number of stays, and medical history were considered important factors in the study.

\section{Materials and methods}

The research was conducted in a group of 60 surgical patients, including 30 hospitalized in Poland and 30 in Ireland. The tools utilized were:

1. the Sense of Coherence Questionnaire for Adults SOC-29 and

2. the Satisfaction with Life Scale (SWLS).

Polish versions of both questionnaires were also used. Based on the literature, the following specific questions were asked:

1 . Is there a correlation between the level of an individual's SOC and their level of SWL?

2. Is there a difference between the strength of the SOC in Polish and Irish patients?

3. Is there a difference between the level of SWL in Polish and Irish patients?

Taking into account the variables being tested, it was assumed that people with a stronger SOC as a global orientation in life, along with its components (comprehensibility, manageability and meaningfulness), experience a relatively higher level of SWL. In addition, it was assumed that in patients hospitalized in Ireland, the levels of both tested variables are higher than in Polish patients, due to better medical care.

\section{Structure of the variables}

The variables included in the study were divided into dependent, independent, categorical, and contextual data. The main dependent variable is the level of SWL. The independent variable is the strength of the SOC and its components. The categorical variable is the country of residence (Poland or Ireland). Contextual variables included age, sex, place of residence, level of education, marital status, the reason for hospitalization, the length of the hospital stay, the number of stays, and medical history.

\section{Stages of the research}

In the research, the correlation model was applied. The research plan consisted of the following stages:

1. Defining the objective and research problems, selecting the variables to be tested:

- SOC,

- SWL. 
2. Selecting appropriate research tools:

- Sense of Coherence Questionnaire - SOC-29 (Polish version),

- Sense of Coherence Questionnaire - SOC-29 (English version),

- SWLS (Polish version),

- SWLS (English version).

3. Psychometric analysis of the tools.

4. Research, conducted in 2 stages:

- pilot studies - May 2011,

- research on patients undergoing surgical treatment using selected research tools - June-August 2011.

5. Analysis of the data obtained, verification of hypotheses.

6. Conclusions.

\section{Selection and characteristics of the research sample}

The study was conducted between May and August 2011 in surgical departments in the Jan Mikulicz-Radecki University Teaching Hospital in Wrocław (Poland), the District Hospital Complex in Oleśnica (Poland) and St. Michael's Hospital in Dun Laoghaire (Ireland).

The primary criterion for selecting the research sample was the waiting period for surgery. Each time before the research, the patients were asked about their physical and mental health, well-being and willingness to participate in the research. The subjects were informed of the voluntary nature of their participation, the aim of the research and that they could withdraw from it at any time. There were 3 patients who did not consent. Prior to the beginning of the research, consent was obtained from the directors of the hospitals and department heads.

The research included 60 patients, 30 in hospitals in Poland and 30 in the hospital in Ireland. All the questionnaires were correctly completed by the participants, in accordance with the instructions attached to the questionnaires, which allowed us to include all of them in our analysis.

The following variables were included in the characteristics of the research sample: the participant's age, sex, level of education, place of residence, marital status, the reason for the hospitalization, the length of the hospital stay, the number of stays, and medical history.
The number of men and women was evenly distributed (50\% from each group). The average age was 47 years. The largest number of people had secondary or higher education (33\% each). The majority of the respondents lived in rural areas or small towns (33\% each), and the majority $(61.7 \%)$ were married. The most common causes of hospitalization were gallbladder disease (20\%), hernia (15\%) and fracture (11.7\%). The majority of the patients remained in the hospital for 2 days (36.7\%). The most common diseases in the respondents' medical histories were hypertension, hernia and heart problems.

\section{Statistical analyses}

SPSS PL v. 19 software (Predictive Solutions Sp. z o.o., Kraków, Poland) was used for the statistical calculations. The level of correlations between variables was determined using the Pearson's correlation coefficient, and differences between the groups (country of residence: Poland or Ireland) were determined using Student's t-test. In addition, the following analyses were performed on the general characteristics of the research group: descriptive statistics, minimum and maximum value (Min and Max), mean (M), standard deviation (SD), frequency, and the KolmogorovSmirnov test. P-values $<0.05$ were regarded as statistically significant.

\section{Results}

The independent variable in the research was the SOC and its components (comprehensibility, manageability and meaningfulness). The strength of the SOC was assessed on the basis of the SOC-29 questionnaire, in which one can score in total between 29 and 203 points. In the research group, the following values were obtained (Table 4):

- for comprehensibility: in patients undergoing surgery in hospitals in Poland, $\mathrm{M}=46.3, \mathrm{SD}=9.8, \mathrm{Min}=28$, $\operatorname{Max}=63$; in Irish patients, $\mathrm{M}=50.8, \mathrm{SD}=9.2, \mathrm{Min}=33$, $\operatorname{Max}=71$;

- for manageability: in patients undergoing surgery in hospitals in Poland, $\mathrm{M}=49.7, \mathrm{SD}=5.07, \mathrm{Min}=37$,

Table 4. Breakdown of the level of the components of the sense of coherence (SOC) in the 2 groups

\begin{tabular}{|l|c|c|c|c|c|}
\hline \multicolumn{1}{|c|}{ Component } & Group & $\begin{array}{c}\text { Number } \\
\text { of participants }\end{array}$ & Min & Max & Mean \\
\hline \multirow{2}{*}{ Comprehensibility } & $\mathrm{PL}$ & 30 & 28 & 63 & 46.3667 \\
\hline \multirow{2}{*}{ Manageability } & $\mathrm{IE}$ & 30 & 33 & 71 & 50.8000 \\
\hline \multirow{2}{*}{ Meaningfulness } & $\mathrm{PL}$ & 30 & 37 & 58 & 49.7333 \\
& $\mathrm{IE}$ & 30 & 38 & 63 & 49.3667 \\
\hline
\end{tabular}

SOC - sense of coherence; PL - Polish participants; IE - Irish participants; SD - standard deviation. 
Table 5. Breakdown of the level of the sense of coherence (SOC) in the 2 groups

\begin{tabular}{|c|c|c|c|c|c|}
\hline & SOC & Results & Polish patients & Irish patients & In total \\
\hline \multirow{6}{*}{$\begin{array}{l}\text { Level } \\
\text { of the SOC }\end{array}$} & \multirow{2}{*}{$\begin{array}{c}\text { low } \\
\text { (below } 117 \text { points) }\end{array}$} & number of persons & 0 & 0 & 0 \\
\hline & & $\%$ of persons & 0 & 0 & 0 \\
\hline & \multirow{2}{*}{$\begin{array}{l}\text { medium } \\
\text { (117-156 points) }\end{array}$} & number of persons & 23 & 21 & 44 \\
\hline & & $\%$ of persons & 76.7 & 70 & 73.7 \\
\hline & \multirow{2}{*}{$\begin{array}{c}\text { high } \\
\text { (over } 156 \text { points) }\end{array}$} & number of persons & 7 & 9 & 16 \\
\hline & & $\%$ of persons & 23.3 & 30 & 26.7 \\
\hline
\end{tabular}

Max $=58 ;$ in Irish patients, $M=49.3 \mathrm{SD}=6.39, \mathrm{Min}=38$, $\operatorname{Max}=63$;

- for meaningfulness: in patients undergoing surgery in hospitals in Poland, $\mathrm{M}=45.5, \mathrm{SD}=4.24, \mathrm{Min}=37$, $\operatorname{Max}=54$; in Irish patients, $\mathrm{M}=44.9 \mathrm{SD}=5.74, \mathrm{Min}=34$, $\operatorname{Max}=56$.

Table 5 shows a breakdown of the strength of the SOC. Average scores (117-156 points) were reported by 23 of Polish patients $(76.7 \%)$ and 21 of Irish patients (79\%). High results (above 156 points) were scored by 7 of Polish patients (23.3\%) and 9 of Irish patients (30\%). A low SOC (below 117 points) did not occur. In general, 44 patients $(73.7 \%)$ had mean SOC scores and 16 (26\%) had high SOC scores. The results are shown in Fig. 3-5.

The dependent variable was the level of SWL, tested using the SWLS questionnaire. The respondents could get between 5 and 35 points. As can be seen from the data in Table 6 , the following values were obtained in the researched group:

- in patients undergoing surgery in hospitals in Poland, $\mathrm{M}=24.6, \mathrm{SD}=5.1, \mathrm{Min}=15, \mathrm{Max}=33$;

- in patients undergoing surgery in hospitals in Ireland, $\mathrm{M}=23.9, \mathrm{SD}=6.1, \mathrm{Min}=8, \mathrm{Max}=35$.

According to the data, the mean level of SWL is similar in the 2 groups. The overall average level of SWL in patients in both countries is $M=24.25$, which in standardized units corresponds to a sten score of 7 . This result indicates that the subjects of the research are characterized by a high level of SWL.

The results of the distribution of the dependent and independent variables tested in both groups are presented in Fig. 6.

\section{Statistical verification of the hypotheses}

The study posited main hypotheses with detailed hypotheses. Their verification on the basis of the results of the research is presented below.

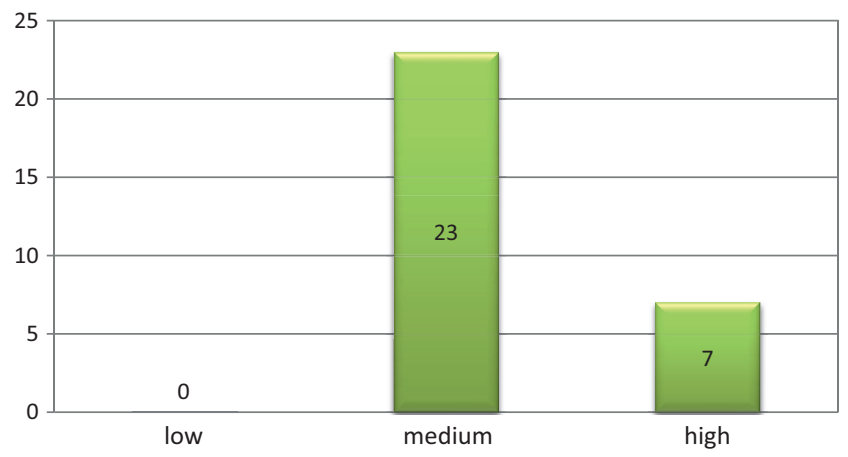

Fig. 3. Distribution of results for the sense of coherence (SOC) in Polish patients in terms of the number of persons

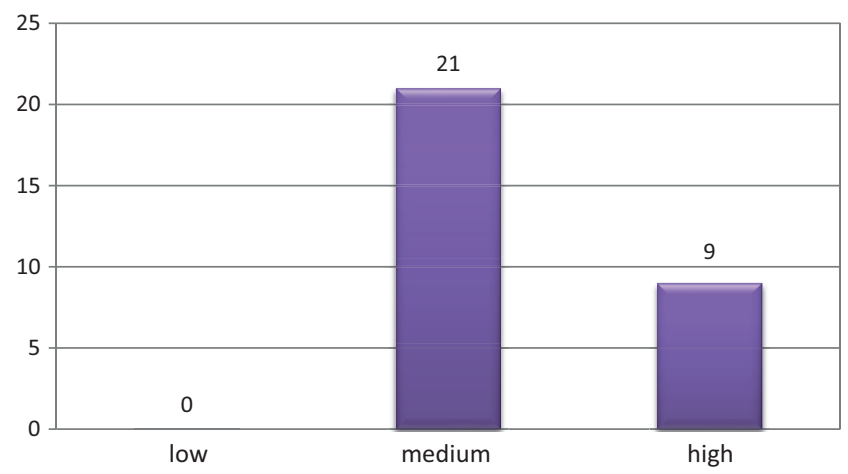

Fig. 4. Distribution of results of the sense of coherence (SOC) in Irish patients in terms of the number of persons

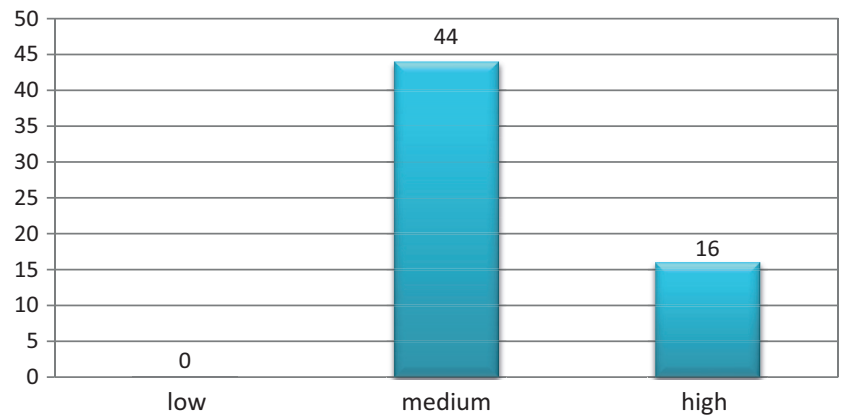

Fig. 5. Distribution of the results of the overall sense (SOC) of coherence in terms of the number of persons

Table 6. Breakdown of the level of SWL in the 2 groups

\begin{tabular}{|l|c|c|c|c|c|c|}
\multicolumn{1}{|c|}{ Variable } & Country & Number & Min & Max & Mean & SD \\
\hline \multirow{2}{*}{ SWLS } & L & 0 & 5 & 3 & 24.6000 & 5.10308 \\
& E & 0 & 8 & 5 & 23.9333 & 6.93169 \\
\hline
\end{tabular}

Min - minimum; Max - maximum; SD - standard deviation; SEM - standard error of the mean; SWLS - Satisfaction with Life Scale. 


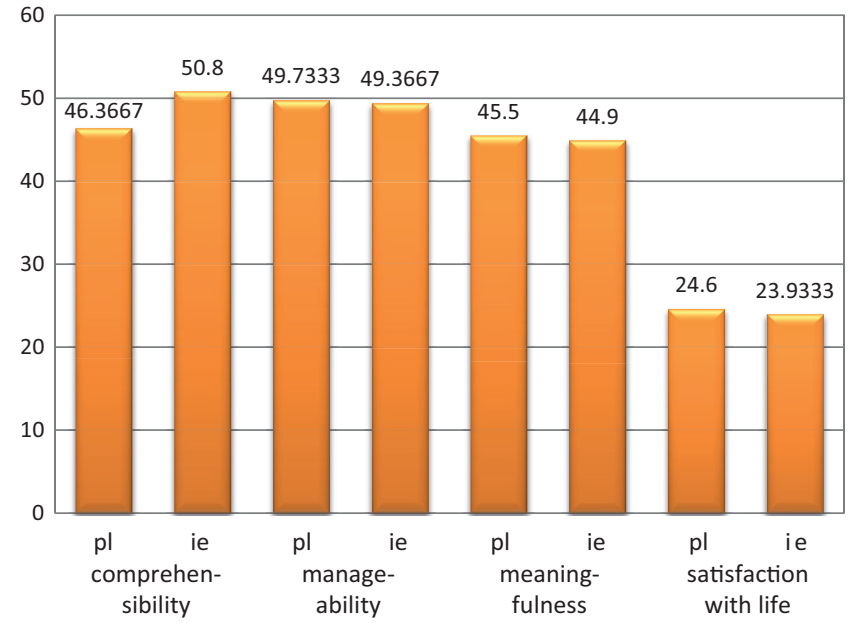

Fig. 6. Distribution of the results of the variables examined in Polish and Irish patients

\section{Hypothesis 1}

In order to verify the first hypothesis, correlations between the results of the SOC-29 and SWLS questionnaires were examined using Pearson's correlation coefficient. The results (presented in Table 7) show that the correlations between the subcategories of the SOC and SWL in the examined patients are as follows.

There was a statistically significant positive correlation between the overall result of the SOC and SWL $(\mathrm{p}<0.01$; $r=0.36$ ). The results show that with an increase in one variable, the second variable increases too, and that with a decrease in one variable, the second variable also decreases.

In addition, the following statistically significant positive correlations were observed:

- between comprehensibility and manageability $(\mathrm{p}<0.01 ; \mathrm{r}=0.36)$,
- between comprehensibility and meaningfulness $(\mathrm{p}<0.01 ; \mathrm{r}=0.37)$,

- between comprehensibility and SWL $(\mathrm{p}<0.05$; $\mathrm{r}=0.26)$.

In each case, the results again show that with an increase in one variable, the second variable increases too, and that with a decrease in one variable, the second variable also decreases.

There was a statistically significant positive correlation between manageability and meaningfulness $(\mathrm{p}<0.001$; $r=0.61$ ). Once more the results show that with an increase in one variable, the second variable increases too, and that with a decrease in one variable, the second variable also decreases.

Thus, there is a connection between all the variables except manageability and SWL. It can be stated that for the first major hypothesis, the detailed hypotheses HOA and $\mathrm{H} 0 \mathrm{C}$ can be rejected in favor of hypotheses $\mathrm{H} 1 \mathrm{~A}$ and $\mathrm{H} 1 \mathrm{C}$. However, there is no reason to reject hypothesis H0B.

\section{Hypothesis 2}

In order to test differences in the level of comprehensibility in the groups of patients hospitalized in Poland and Ireland, Student's t-test for independent samples was used $(\mathrm{t}[58]=-1.797, \mathrm{p}=0.078)$. The result of the analysis indicates that there are no differences between the 2 groups in terms of comprehensibility. This means there are no grounds for rejecting the zero hypothesis. The data obtained are presented in Table 8.

Student's t-test for independent samples was also used to test differences in the level of manageability in the groups of patients hospitalized in Poland and Ireland $(\mathrm{t}[58]=0.246, \mathrm{p}=0.807)$. The result again indicates that there are no differences between the 2 groups in terms of manageability, and that there are no grounds

Table 7. Correlations between particular subscales of the sense of coherence (SOC) and the satisfaction with life (SWL)

\begin{tabular}{|c|c|c|c|c|c|c|}
\hline Variable & Parameter & Comprehensibility & Manageability & Meaningfulness & SOC & SWL \\
\hline \multirow{3}{*}{ Comprehensibility } & Pearson's correlation & 1 & 0.360 & 0.374 & 0.836 & 0.257 \\
\hline & significance (bilateral) & - & 0.005 & 0.003 & 0.000 & 0.048 \\
\hline & number of persons & 60 & 60 & 60 & 60 & 60 \\
\hline \multirow{3}{*}{ Manageability } & Pearson's correlation & 0.360 & 1 & 0.605 & 0.752 & 0.234 \\
\hline & significance (bilateral) & 0.005 & - & 0.000 & 0.000 & 0.071 \\
\hline & number of persons & 60 & 60 & 60 & 60 & 60 \\
\hline \multirow{3}{*}{ Meaningfulness } & Pearson's correlation & 0.374 & 0.605 & 1 & 0.750 & 0.403 \\
\hline & significance (bilateral) & 0.003 & 0.000 & - & 0.000 & 0.001 \\
\hline & number of persons & 60 & 60 & 60 & 60 & 60 \\
\hline \multirow{3}{*}{ SOC } & Pearson's correlation & 0.836 & 0.752 & 0.750 & 1 & 0.357 \\
\hline & significance (bilateral) & 0.000 & 0.000 & 0.000 & - & 0.005 \\
\hline & number of persons & 60 & 60 & 60 & 60 & 60 \\
\hline \multirow{3}{*}{ SWL } & Pearson's correlation & 0.257 & 0.234 & 0.403 & 0.357 & 1 \\
\hline & significance (bilateral) & 0.048 & 0.071 & 0.001 & 0.005 & - \\
\hline & number of persons & 60 & 60 & 60 & 60 & 60 \\
\hline
\end{tabular}


Table 8. Results of Student's t-test for independent samples for the variable comprehensibility

\begin{tabular}{|c|c|c|}
\multicolumn{1}{|c|}{$\mathrm{T}$} & $\mathrm{df}$ & Significance \\
\hline-1.797 & 58 & 0.78 \\
\hline
\end{tabular}

T-Student's t-test; df - degrees of freedom.

Table 9. Results of Student's t-test for independent samples for the variable manageability

\begin{tabular}{|c|c|c|}
\hline \multicolumn{1}{|c|}{ T } & df & Significance \\
\hline 0.246 & 58 & 0.807 \\
\hline
\end{tabular}

T-Student's t-test; df - degrees of freedom.

Table 10. Results of Student's t-test for independent samples for the variable meaningfulness

\begin{tabular}{|c|c|c|}
\hline \multicolumn{1}{|c|}{ T } & df & Significance \\
\hline 0.406 & 58 & 0.647 \\
\hline
\end{tabular}

T-Student's t-test; df - degrees of freedom.

Table 11. Results of Student's t-test for independent samples for the variable satisfaction with life

\begin{tabular}{|c|c|c|}
\hline \multicolumn{1}{|c|}{$\mathrm{T}$} & $\mathrm{df}$ & Significance \\
\hline 0.458 & 58 & 0.648 \\
\hline
\end{tabular}

$\mathrm{T}$-Student's t-test; $\mathrm{df}$ - degrees of freedom.

for rejecting the zero hypothesis. The data obtained are presented in Table 9.

When Student's t-test for independent samples was used to test differences in the level of meaningfulness in the 2 groups of patients, the result $(\mathrm{t}[58]=0.46, \mathrm{p}=0.647)$ once again indicated that there are no differences between the 2 groups in terms of meaningfulness. Again, this means there are no grounds for rejecting the zero hypothesis. The data obtained are presented in Table 10.

Therefore, the results of the analysis indicates, therefore, that there are no differences between the groups of Polish and Irish patients in terms of the SOC and its components.

\section{Hypothesis 3}

In order to test differences in the level of SWL in the compared groups of patients hospitalized in Poland and Ireland, Student's t-test for independent samples was used. The result of the analysis $(\mathrm{t}[58]=0.458, \mathrm{p}=0.648)$ indicates that there are no differences between the 2 groups in terms of SWL. This means there are no grounds for rejecting the zero hypothesis H30. The data obtained is presented in Tables 11,12.

\section{Conclusions}

Analyzing the results of our research, we formulated the following conclusions:

1. The study group has a high average level of SWL.

2. Most of the respondents got an average score for the SOC.

3. There are relationships between particular subscales of the SOC, i.e., comprehensibility, manageability and meaningfulness, with the highest correlation between manageability and meaningfulness $(r=0.61)$.

4. Patients who are characterized by a strong SOC are probably also characterized by a high level of SWL.

5. Patients who are characterized by an average SOC are probably also characterized by an average level of SWL.

6. In the study group, increases in the SOC were accompanied by increases in the level of SWL, and decreases in the SOC mean the level of SWL decreases too.

7. Correlations were demonstrated among the components of the SOC (comprehensibility, manageability and meaningfulness).

8. There is no significant correlation between the manageability component of the SOC and SWL.

9. None of the patients had a low level of the SOC.

10. There were no significant differences between patients hospitalized in Polish and Irish hospitals in terms of the SOC and its components.

Table 12. Significance of the differences in the level of satisfaction with life (SWL) for independent groups: Polish participants compared to Irish ones

\begin{tabular}{|c|c|c|c|c|c|c|c|c|c|c|}
\hline \multirow{3}{*}{ Method } & \multirow{3}{*}{ Variables } & \multicolumn{2}{|c|}{$\begin{array}{c}\text { Levene's test of } \\
\text { the equation } \\
\text { of variance }\end{array}$} & \multicolumn{7}{|c|}{ t-test of the equality of means } \\
\hline & & \multirow[t]{2}{*}{$\mathrm{F}$} & \multirow{2}{*}{ significance } & \multirow[t]{2}{*}{$\mathrm{t}$} & \multirow[t]{2}{*}{ df } & \multirow{2}{*}{$\begin{array}{l}\text { significance } \\
\text { (bilateral) }\end{array}$} & \multirow{2}{*}{$\begin{array}{l}\text { difference } \\
\text { in means }\end{array}$} & \multirow{2}{*}{$\begin{array}{l}\text { standard error } \\
\text { of the difference }\end{array}$} & \multicolumn{2}{|c|}{$\begin{array}{l}95 \% \mathrm{Cl} \text { for the difference } \\
\text { in means }\end{array}$} \\
\hline & & & & & & & & & lower limit & upper limit \\
\hline \multirow[b]{2}{*}{ SWLS } & $\begin{array}{l}\text { equation } \\
\text { of variance } \\
\text { is assumed }\end{array}$ & 1.019 & 0.317 & 0.458 & 58 & 0.648 & 0.66667 & 1.45471 & -2.24524 & 3.57858 \\
\hline & $\begin{array}{l}\text { equation } \\
\text { of variance } \\
\text { is not } \\
\text { assumed }\end{array}$ & - & - & 0.458 & 56.187 & 0.649 & 0.66667 & 1.45471 & -2.24724 & 3.58058 \\
\hline
\end{tabular}

$\mathrm{Cl}$ - confidence interval; df - degrees of freedom; SWLS - Satisfaction with Life Scale. 
11. There were no significant differences between patients hospitalized in Polish and Irish hospitals in terms of the level of SWL.

12. Therefore, the country of hospitalization does not significantly differentiate the remaining variables analyzed in the study.

\section{References}

1. Antonovsky A. Rozwikłanie tajemnicy zdrowia. Jak radzić sobie ze stresem inie zachorować. Warszawa, Poland: Instytut Psychiatrii i Neurologii; 2005:7-8,11,34,43,106-107,175-178.

2. Juczyński Z. NPPPZ-Narzędzia pomiaru w promocji i psychologiizdrowia. $2^{\text {nd }}$ ed. Warszawa, Poland: Pracownia Testów Psychologicznych Polskiego Towarzystwa Psychologicznego; 2009.

3. Trzebiatowski J. Jakość życia w perspektywie nauk społecznych i medycznych - systematyzacja ujęć definicyjnych. Hygeia Public Health. 2011;46(1):25-31.

4. Heszen I, Sęk H. Psychologia zdrowia. Warszawa, Poland: Wydawnictwo Naukowe PWN; 2008:56-57,78.

5. Antonovsky A. Health, Stress and Coping. San Francisco, USA: JosseyBass Inc.; 1979:49,72.

6. Sęk H. Psychologia kliniczna. Tom 1. Warszawa, Poland: Wydawnictwo Naukowe PWN; 2005.
7. Turosz AM. Zasoby osobiste i deficyty a jakość życia studentów Akademii Wychowania Fizycznego w Warszawie. Probl Hig Epidemiol. 2011:92(2):204-210.

8. Kane RA. Quality of life. In: Breslow L. ed. Encyclopaedia of Public Health. Vol. 3. $2^{\text {nd }}$ ed. New York, USA: Macmillan Library Reference; 2002:1003-1006.

9. Zawiślak A. Koncepcja jakości życia osób z upośledzeniem umysłowym w niektórych współczesnych ujęciach teoretycznych. In: PalakZ, Lewicka A, Bujnowska A. Jakość życia a niepełnosprawność. Lublin, Poland: Wydawnictwo UMCS; 2006:149-158.

10. Schalock RL, Brown I, Brown R, et al. Conceptualization, measurement, and application of quality of life for persons with intellectual disabilities: Report of an international panel of experts. Ment Retard. 2002;40(6):457-470. doi:10.1352/0047-6765(2002)040<0457:CMAAOQ $>2.0 . \mathrm{CO} ; 2$

11. Raphael D, Brown I, Renwick R. Psychometric properties of the full and short versions of the Quality of Life Instrument Package: Results from the Ontario province-wide study. Int/ J Disabil Dev Educ. 1999;46(2): 157-168. doi:10.1080/103491299100605

12. Schalock RL. Three decades of quality of life. Focus Autism Other Dev Disabl. 2000;15(2):116-127. doi:10.1177/108835760001500207

13. Cummins RA. The subjective well-being of people caring for a severely disabled family member at home: A review. J Intellect Dev Disabil. 2001;26(1):83-100. doi:10.1080/13668250020032787

14. Diener E. Subjective well-being. Psychol Bull. 1984;95(3);542-575.

15. Shin C, Johnson DM. Avowed happiness as an overall assessment of the quality of life. Soc Indic Res. 1978;5:475-492. doi:10.1007/BF0 0352944 